\title{
Surface Characteristics and Physical Properties of Cotton Fabric for Patient Clothing Material through a Chitosan/Nanosilver Colloidal Solution
}

\author{
Kyoung-Mi Jeong $\cdot$ Hyun-Sook Bae ${ }^{\dagger}$ \\ Dept. of Clothing \& Textiles, Changwon National University
}

Received July 10, 2009; Revised (August 19, 2009; September 18, 2009); Accepted October 7, 2009

\author{
환자복 소재용 면직물의 키토산/은나노 \\ 콜로이드용액 처리에 따른 표면 특성과 물리적 성질 \\ 정경미·배현숙 \\ 창원대학교 의류학과 \\ 접수일(2009년 7월 10일), 수정일(1차 : 2009년 8월 19일, 완료일 : 2009년 9월 18일), 게재확정일(2009년 10월 7일)
}

\begin{abstract}
Hospital patient clothing material was treated with a mixture of chitosan in order to enhance functionality, such as the durability and dimensional stability of the cotton fabric used. Chitosan is a natural polymer with excellent biocompatibility, however there is a deteriorating adherence efficiency. The addition of a nanosilver colloidal solution in accordance with a prescribed ratio can further increase the performance of chitosan. Changes in the structural characteristics and physical properties of the chitosan/nanosilver treated fabric were observed in a comparison with fabric treated only with chitosan. The add-on ratio increased when the mixing ratio of nanosilver colloidal solution was higher; however, the crystalline structure of the treated fabric remains similar. In the case of $\mathrm{CH} / \mathrm{NS} 1$ treated fabric (where the mixing ratio of chitosan and nanosilver solution was 3:1) the $K / S$ value, whiteness index, wet tensile strength, and wrinkle recovery angle were superior. The dimension stability, pilling resistance, and abrasion resistance of the fabric treated with a mixed solution increased in comparison to the fabric treated only with chitosan. The chitosan/nanosilver treated cotton fabric used for patient clothing material has excellent physical properties.
\end{abstract}

Key words: Cotton fabric for patient clothing material, Chitosan, Nanosilver colloid, Physical properties; 환자복 소재, 키토산, 은나노 콜로이드, 물리적 성질

\section{Introduction}

A natural hygienic textile is necessary for patient clothing as it alleviates the adverse impact on body

Corresponding author

E-mail: hsbae@changwon.ac.kr

This work was supported by grant No. (R01-2005-00010143-0) from the Basic Research Program of the Korea Science \& Engineering Foundation. temperature regulation, defense against germs, physical activities, and frees the body of direct contact with the skin. Patient clothing is desirable as a fabric that minimizes skin irritation through natural textiles with outstanding tactile qualities without causing allergic reactions. However, patient clothing needs frequent sanitization, and a fabric with outstanding durability that does not deteriorate through laundering or chemical treatments, is non-shrinkable, and is wrinkle free 
must be selected (Park et al., 2006). The improvement of tactile sensation and performance are important, as patient clothing must not restrict the movement of the body since it is in direct contact with the skin. The structural and physical properties of the fabric must be suitable for wear by patients.

The majority of research on patient clothing is about construction, design, and the wearing conditions of patient clothing (Hong, 1999; Park, 2006), with limited mention of conditions for material used for patient clothing. The research on the improvement of the functionality of material used for patient clothing from the perspective of structural and physical properties is inadequate. Chitosan is a natural compound that can be used as a finishing agent to modify the structural and physical properties of cotton fabric used for patient clothing with an application towards the human body that can satisfy the susceptibility aspects with a relatively simple reaction process (Lee et al., 1994).

Chitosan has outstanding biodegradability and biocompatibility without causing environmental pollution. It has composite functions that include antibacterial, deodorization, and moisturizing effects (Kim et al., 1997; Ogura et al., 1980; Samuels, 1981), and is a useful natural polymer that can be recycled (Xu et al., 1996). However, a resin or a cross-linking agent should be used to enhance the adhesion efficiency of chitosan, which negatively affects the feeling and durability associated with washing; in addition, friction is also problematic (Kim et al., 1995). A tedious process of multiple treatment steps with a cross linking agent and a softening agent are required to remedy the shortcomings of chitosan. Such processes are complicated and increase the costs. For economic reasons silver should be mixed with chitosan as a finishing agent in order to increase the finishing effect. Silver is non-toxic (Simpson, 2003) and enhances the functionality when mixed with chitosan.

Silver is a non-toxic inorganic metal with effectiveness in the removal of microbes such as harmful germs and molds thriving in natural fibers, and unlike other finishing agents, displays outstanding antibiotic properties even in minute quantities (Hong et al., 1998). Nanosized silver particles have a greater total surface area than silver with equal volume. In addition, silver is skin-friendly and does not induce skin irritation (Lee \& Jeong, 2002). As a result, treatment efficiency can be enhanced by mixing in small quantities of nanosilver colloidal solution.

To enhance the functionality (such as durability and dimensional stability of a cotton fabric actually used for patient clothing material) the fabric was treated with a mixture of chitosan, which is a natural polymer with excellent biocompatibility, and nanosilver colloidal solution, for which an additional performance can be expected while supplementing the weaknesses of chitosan, in accordance with the prescribed ratio. Changes in the structural and physical properties of the chitosan/nanosilver treated fabric were observed by comparing the fabric treated only with chitosan. Then, the applicability of chitosan/nanosilver treated cotton fabric used for the patient clothing material was examined and evaluated.

\section{Experimental}

\section{Materials}

A cotton fabric for the patient clothing material was provided by Silverday Co.. The characteristics of the fabric are shown in <Table 1>. The reagent used for the mixed solution of chitosan (DD=95.3\%, 40,000ppm) and nanosilver colloid (below 10nm, 30,000ppm) was provided by Texan Med. Tech. Co., Ltd..

\section{Methods}

\section{1) Treatment of the Fabric}

A cotton fabric was treated with mixed solutions of chitosan $(\mathrm{CH})$ and nanosilver (NS) which were mixed

Table 1. Characteristics of the fabric

\begin{tabular}{|c|c|c|c|c|c|c|}
\hline \multirow{2}{*}{ Fabric } & \multirow{2}{*}{ Weave } & \multirow{2}{*}{ Yarn count } & \multicolumn{2}{|c|}{ Fabric count (threads/inch) } & \multirow{2}{*}{$\begin{array}{l}\text { Weight } \\
\left(\mathrm{g} / \mathrm{m}^{2}\right)\end{array}$} & \multirow{2}{*}{$\begin{array}{c}\text { Thickness } \\
(\mathrm{mm})\end{array}$} \\
\hline & & & Warp & Weft & & \\
\hline Cotton $100 \%$ & twill & $20 \mathrm{~s} \times 16 \mathrm{~s} / 1$ & 102 & 58 & 198 & 0.40 \\
\hline
\end{tabular}


at ratios of 3:1 (CH3/NS1), 1:1 (CH1/NS1), and 1:3 (CH1/NS3). The fabrics treated with these solutions were compared with the fabric that was treated only with chitosan (CH4). A carboxylic acid $(0.1 \mathrm{~mol} / \ell)$ as a cross linking agent was first added to the chitosan/ nanosilver colloidal solution and chitosan only solution. The treatment was performed with one bath processing. The fabric was immersed in the solution at the liquor ratio of 40:1 for $1 \mathrm{hr}$, and padded for its wet pick-up at $100 \pm 2 \%$. The fabric was dried naturally and then heated for $3 \mathrm{~min}$. at $160^{\circ} \mathrm{C}$. Then, to determine the add-on ratio of the treated fabric, the specimen was dried completely at $105^{\circ} \mathrm{C}$, and weighed before and after drying.

\section{2) Surface Characteristics of the Fabric}

In order to compare the surface adhesion condition of treated fabric in accordance with the mixing ratio of the chitosan/nanosilver colloidal solution, Au-Pd was vacuum deposited onto the surface of chitosan/ nanosilver treated fabric, and then the surface was observed using a scanning electron microscope (JSM5610, Joel).

C. I. Acid Red 88 was used to examine the cationization of the chitosan/nanosilver treated fabric in terms of apparent dye uptake. The dyeing solution was admixture of acid dye $2 \%$ (o.w.f.), $\mathrm{Na}_{2} \mathrm{SO}_{4} 15 \%$ (o.w.f.), $\mathrm{H}_{2} \mathrm{SO}_{4} 3 \%$ (o.w.f.), and $\mathrm{CH}_{3} \mathrm{COOH} 5 \%$ (o.w.f.). The dyeing method was processed by $\langle$ Scheme 1$\rangle$. Surface reflectance was measured at the maximum optical density using a spectrophotometer (Minolta, CM-3600d) and evaluated as a $K / S$ value. The color difference $(\Delta \mathrm{E})$ was measured by dyeing of treated and untreated fabric according to the CIE surface color system. The whiteness index was examined using a color difference meter according to the CIE surface color system.

In order to verify the internal crystalline structure of the fabric, X-ray diffraction patterns (WAXD) were examined using X-ray diffractometer (X'PERT MPD3040, Philips) in a scanning range of $5 \sim 40^{\circ}$ at the rate of $5 \% \mathrm{~min}$. Thermal analysis was carried out under nitrogen gas at temperatures up to $450^{\circ} \mathrm{C}$ using a thermal analyzer (TA5000/SDT 2960/DSC Q10).

\section{3) Physical Properties of the Fabric}

Tensile strength was measured by revelled strip method (KS K 0522) at the rate of $100 \mathrm{~mm} / \mathrm{min}$ in the direction of warp. The wet tensile strength was measured after dipping for 1 hour in distilled water at $20^{\circ} \mathrm{C}$. A Cantilever softness tester (Daiei Kaguku Seiki) was used to measure the stiffness using a cantilever method (KS K 0539) in the direction of warp. Wrinkle resistance was measured using a Mosanto tester (Yasuda Seiki, YSS M0342) by the angle of the recovery method (KS K 0550) in the direction of warp and weft.

Dimensional stability was examined by a wash wheel method (KS K 0600-2001), pilling resistance was measured using a pilling tester (Custom scientific pilling tester; Model CS-53) by brush and sponge method (KS K 0501), and abrasion resistance was measured using a Martindale abrasion tester by the Martindale method (KS K 0604-1995) under 9KPa.

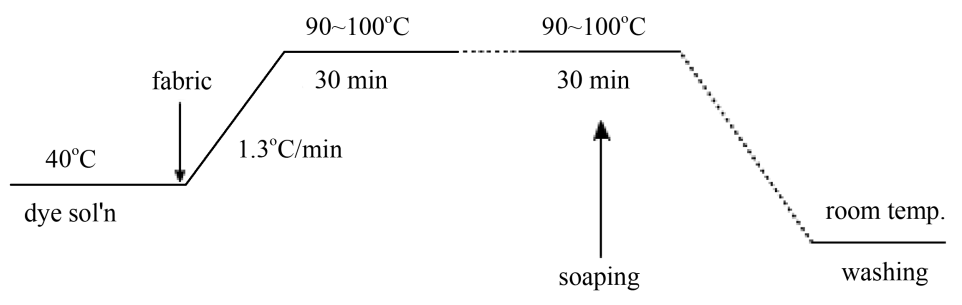

$\Delta \mathrm{E}=\sqrt{\left(\Delta \mathrm{L}^{*}\right)^{2}+\left(\Delta \mathrm{a}^{*}\right)^{2}+\left(\Delta \mathrm{b}^{*}\right)^{2}}$

$\Delta \mathrm{L}^{*}=\mathrm{L}_{1}-\mathrm{L}_{2}, \Delta \mathrm{a}^{*}=\mathrm{a}_{1}-\mathrm{a}_{2}, \Delta \mathrm{b}^{*}=\mathrm{b}_{1}-\mathrm{b}_{2}$

$L_{1}, a_{1}, b_{1}$ : value of CIE Lab before washing

$L_{2}, a_{2}, b_{2}$ : value of CIE Lab after washing

Scheme 1. Dyeing diagram of acid dye 
The same specimen was tested 5 times to obtain the average value.

\section{Results and Discussion}

\section{Structural Characteristics of the Fabric}

Surface characteristics of the fabric changes when cotton fabric is treated with a chitosan/nanosilver mixed solution, and it is deemed that the treatment will also change the tactile sensations of the fabric. A quantification of the tactile sensation is possible by measuring the values of mechanical properties. Changes in the surface characteristics were found by examining the extent of the adhesion of the treatment agent and directly observing the surface conditions. SEM photographs were compared in order to examine the adhesion condition of the fabric surface. The treatment concentration of the chitosan/nanosilver colloidal solution was $200 \mathrm{ppm}$.

<Fig. 1> shows the surface condition of the treated fabric according to the mixing ratio of the chitosan and nanosilver solution. The evidence of adhesion overall is not distinct because very small quantity of finishing agent was used. Many chitosan particles were observed in the case of the sample (c) for which the ratio of chitosan is the highest among the mixed solution, and surface was smoother with a higher mixing ratio of nanosilver solution due to lower extent of adhesion of chitosan particle on the fabric surface.

In the case of the sample (b) treated with chitosan only at a concentration equal to that of mixed solution, there was less trace of the adhesion of chitosan on the fabric surface in comparison to the sample (c) treated with a solution containing a small quantity of nanosilver solution. This is thought to be caused by the elevation of the adhesion efficiency of chitosan, which is strongly adhered to the fiber surface through physical and chemical bonds (Oh et al., 1997), due to a high surface energy resulting from the extremely fine particles of nanosilver colloidal solution. However, it is hypothesized that the adhesion of particles onto the surface is less, in the case of samples (c) and (d) due to lower ratio of chitosan in the mixed solution. Therefore, as it was difficult to compare the extent of adhesion of the chitosan/nanosilver colloidal solution only by observing SEM photographs; the actual extent of adhesion was evaluated by measuring changes in the weight.

As shown in <Table 2> the add-on ratio of the fabric treated with $200 \mathrm{ppm}$ chitosan/nanosilver colloidal
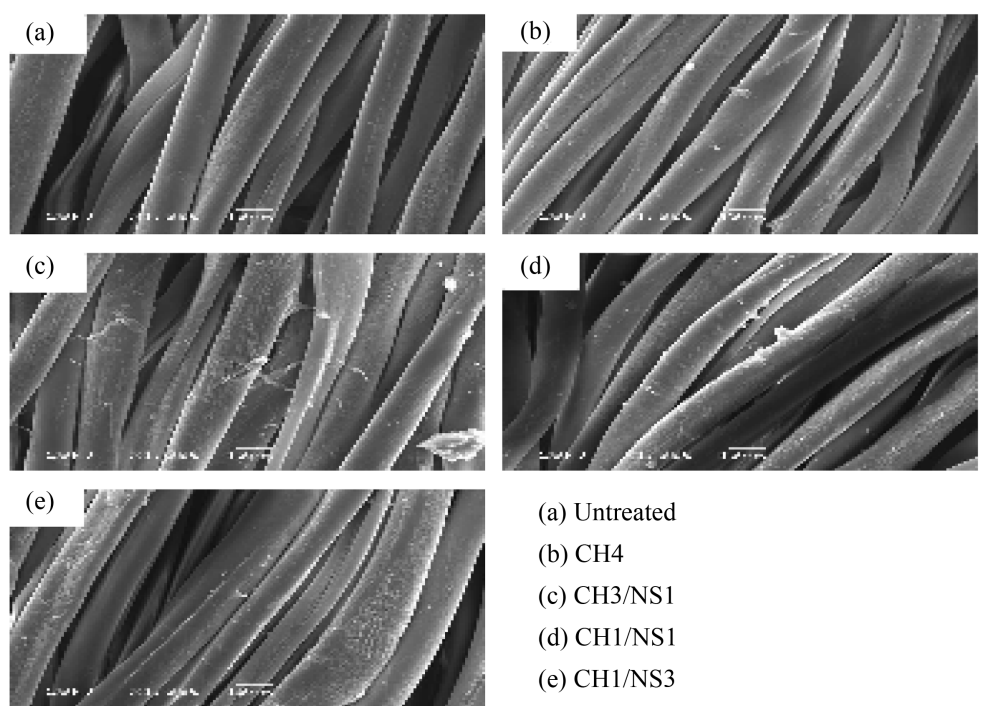
(a) Untreated
(b) $\mathrm{CH} 4$
(c) $\mathrm{CH} 3 / \mathrm{NS} 1$
(d) $\mathrm{CH} 1 / \mathrm{NS} 1$
(e) $\mathrm{CH} 1 / \mathrm{NS} 3$

Fig. 1. Scanning electron micrographs $(\times 1000)$ of the fabrics treated with a chitosan/nanosilver colloidal solution. 
Table 2. Add-on ratio of the fabrics treated with a 200ppm chitosan/nanosilver colloidal solution

\begin{tabular}{c|c}
\hline \hline Samples & Add-on ratio \\
\hline $\mathrm{CH} 4$ & $0.21 \%$ \\
\hline $\mathrm{CH} 3 / \mathrm{NS} 1$ & $0.29 \%$ \\
\hline $\mathrm{CH} 1 / \mathrm{NS} 1$ & $0.44 \%$ \\
\hline $\mathrm{CH} 1 / \mathrm{NS} 3$ & $0.54 \%$ \\
\hline
\end{tabular}

solution was examined. The add-on ratio of the fabric treated with mixed solution was higher than that treated only with chitosan, and the add-on ratio increased with a higher content of nanosilver solution. The higher add-on ratio with a higher content of nanosilver is thought to be due to the higher weight of silver compared to chitosan, as the add-on ratio was calculated by measuring the weight change as well as due to adhesion of minute nanosilver particles onto natural twists or pores of the cotton fiber. Although the adhesion quantity was higher with the higher content of nanosilver solution, the fabric was dyed with an acid dye (C. I. Acid Red 88) in order to indirectly find out the extent of the actual adhesion of chitosan in the mixed solution and to verify the cationization of fabric due to adhesion of chitosan.

The apparent dyeability was measured through $K / S$ value and color difference between the treated fabric and the untreated fabric. In this way, the attachment degree of chitosan according to the cationization was indirectly compared. As cellulose fiber and acid dye (an anionic dye) have negative electric charges in an aqueous solution and is seldom dyed due to mutual repulsion. However, the surface electric charge changes due to the introduction of a cationic amine group through a chitosan treatment and a cotton fabric can be dyed by acid dye and electrical attraction. Therefore, dyeability with acid dye was examined in order to verify the cationization of the chitosan treated fabric. According to $\langle$ Fig. $2>$, the $K / S$ value was obtained by measuring the surface reflectance of the fabric dyed with acid dye; overall, the $K / S$ value was low. This result is similar to that observed in SEM and due to the usage of low concentration of chitosan/ nanosilver mixed solution. The $K / S$ value is relatively high when the mixing ratio of chitosan/nanosilver colloidal solution is at 3:1 and coincides with the state of adhesion observed in SEM photographs.

To compare the chitosan attachment degree of specimens, color difference of the treated fabric was measured according to the mixing ratio. According to $<$ Table 3>, the color difference of the treated fabric was greater with a higher content of chitosan in the chitosan/nanosilver colloidal solution. This means the bonding of the cationic amine of chitosan with acid dye, extent of adhesion of chitosan can be determined indirectly. However, the color difference of the fabric treated only with chitosan was lower than the $\mathrm{CH} 3 / \mathrm{NS} 1$ treated fabric, which is thought to be caused by a stronger adherence onto chitosan as

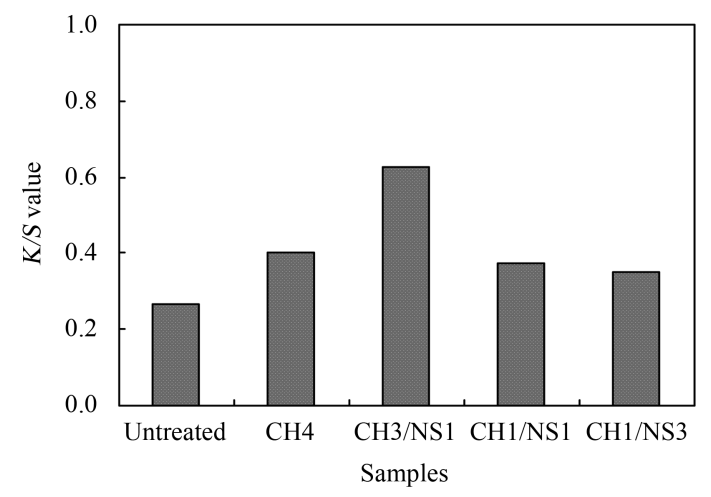

Fig. 2. $K / S$ value of the fabrics treated with chitosan/ nanosilver colloidal solution.

Table 3. Dyeability of acid dye on the fabrics treated with chitosan/nanosilver colloidal solution

\begin{tabular}{c|c|c|c|c}
\hline Samples & $\mathrm{L}^{*}$ & $\mathrm{a} *$ & $\mathrm{~b} *$ & $\Delta \mathrm{E}^{*} \mathrm{ab}$ \\
\hline Untreated & 72.19 & 23.22 & -9.80 & - \\
\hline $\mathrm{CH} 4$ & 66.48 & 28.38 & -5.29 & 8.93 \\
\hline $\mathrm{CH} 3 / \mathrm{NS} 1$ & 64.69 & 29.25 & -3.04 & 11.76 \\
\hline $\mathrm{CH} 1 / \mathrm{NS} 1$ & 69.08 & 25.83 & -6.95 & 4.96 \\
\hline $\mathrm{CH} 1 / \mathrm{NS} 3$ & 70.15 & 24.72 & -8.41 & 2.89 \\
\hline
\end{tabular}


nanosilver was deposited in the case of the mixed solution and showed a tendency similar to the add-on ratio.

The yellowing phenomenon of the chitosan treated fabric affect the external performance of textile products, and has been pointed out as an unavoidable weakness. In particular, as silver particles discolor easily by chemicals such as sulfide in the air, there is a need to examine the whiteness of the chitosan/ nanosilver treated fabric.

As shown in 〈Fig. 3〉, the whiteness index of the chitosan/nanosilver treated fabric was examined. According to this, the whiteness index of the chitosan/nanosilver treated fabric showed slight increase in comparison to the fabric treated only with chitosan, but the difference in the whiteness index in accordance with the mixing ratio of nanosilver colloidal solution was minuscule. It is thought that the chitosan used in this research, which is highly pure product with a low content of residual impurities such as calcareous matters and protein, does not lower the whiteness index of the treated fabric. The silver particle is of a nano structure and it is thought that the whiteness index was improved due to even distribution of glossy nanosilver particles.

In order to examine the change in the internal structure of the chitosan/nanosilver treated fabric, Xray diffraction patterns were analyzed as shown in <Fig. 4>.

Diffraction patterns are observed on the (002) plane around $2 \theta=22.6^{\circ}$, and (101) plane, $(10 \overline{1})$ plane around

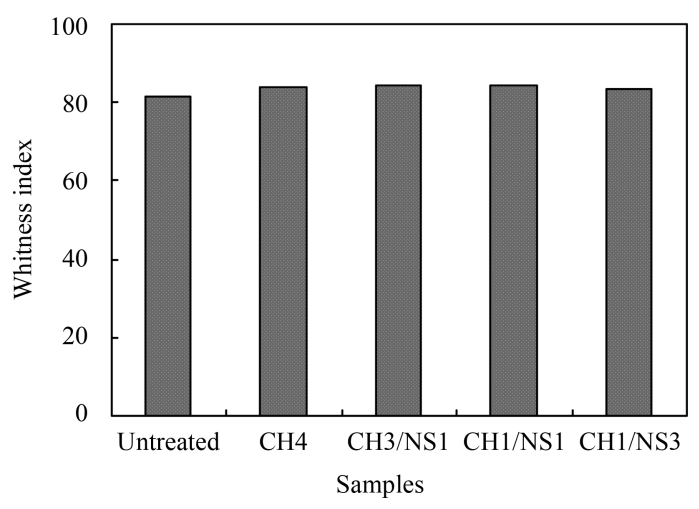

Fig. 3. The whiteness index of the fabrics treated with chitosan/nanosilver colloidal solution.
$2 \theta=14.7^{\circ}, 16.3^{\circ}$ respectively of cellulose I. Although the strength of diffraction patterns increased slightly with a higher mixing ratio of chitosan/nanosilver colloidal solution, the structure of cellulose I of the cotton fabric showed almost no change. In addition, <Table 4> shows thermal stability of chitosan/nanosilver treated fabric obtained through thermogravimetric analysis. According to this, temperature of maximum disintegration $\left(\mathrm{T}_{\max }\right)$ due to chitosan/nanosilver colloidal solution treatment displayed slight difference, which showed the lowest in the chitosan only treated fabric. This means that thermal stability of the chitosan/nanosilver treated fabric was slightly better than the chitosan only treated fabric. It coincides with the research outcome of the cotton fabric treated with chitosan (Oh et al., 1997). In addition, the ratio of residue at $450^{\circ} \mathrm{C}$ was the lowest when the mixing ratio of chitosan/nanosilver colloidal solution is 3:1, thereby indicating the smallest quantity of char was generated.

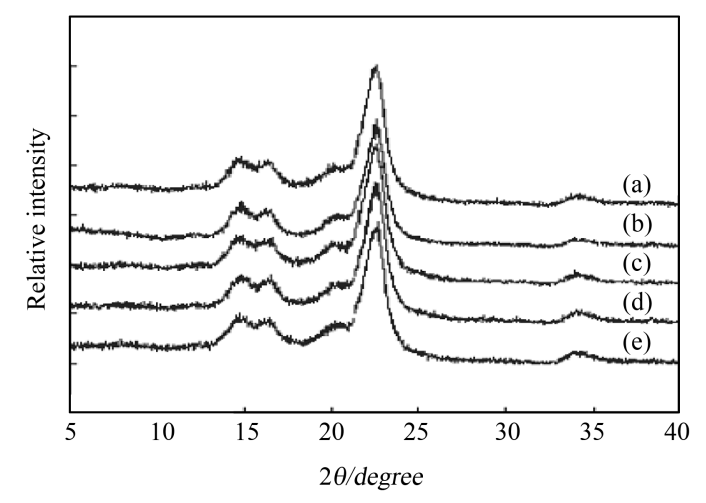

Fig. 4. X-ray diffraction patterns of the fabrics treated with chitosan/nanosilver colloidal solution ((a) Untreated, (b) CH4, (c) CH3/NS1, (d) CH1/NS1, (e) $\mathrm{CH} 1 / \mathrm{NS} 3$ ).

Table 4. TGA of the fabrics treated with chitosan/ nanosilver colloidal solution

\begin{tabular}{c|c|c}
\hline \hline Samples & $\mathrm{T}_{\max }\left({ }^{\circ} \mathrm{C}\right)$ & $\%$ residue at $450^{\circ} \mathrm{C}$ \\
\hline Untreated & 336.30 & 5.63 \\
\hline $\mathrm{CH} 4$ & 332.00 & 9.38 \\
\hline $\mathrm{CH} 3 / \mathrm{NS} 1$ & 332.48 & 7.26 \\
\hline $\mathrm{CH} 1 / \mathrm{NS} 1$ & 333.63 & 9.08 \\
\hline $\mathrm{CH} 1 / \mathrm{NS} 3$ & 337.75 & 9.15 \\
\hline
\end{tabular}




\section{Physical Properties of the Fabric}

Patient clothing must not shrink or the durability be reduced by industrial laundering, and requires external properties of being wrinkle-free without restricting body movement or performance over a long period of time. The physical properties of the chitosan/nanosilver treated fabric were also examined.

$<$ Fig. 5> shows tensile strength during dehydration and humidification after having treated the cotton fabric with the chitosan/nanosilver mixed solution. The tensile strength of the chitosan/nanosilver treated fabric improved in comparison to the untreated fabric, which is thought to be the result of the hindrance movement of fibers due to the treatment with the chitosan/nanosilver colloidal solution, thereby preventing fabric from being stretched easily, coinciding with findings in previous research (Jeong et al., 2009). Dry tensile strength is larger for higher mixing ratio of chitosan, which is thought to be caused by the sedimentary adherence of chitosan.

Wet tensile strength increased the most when the ratio of chitosan/nanosilver colloidal solution was $3: 1$, and the wet tensile strength of all the specimens showed a larger value in comparison to the dry tensile strength. Generally, intermolecular crosslinking are formed in the amorphous region of the fabric when cellulose fabricis treated with a finishing agent, and $t$, and $t$,forces are concentrated on the newly formed intermolecular crosslinking. This causes a hydrogenntend that ngintains the strength of the cellulose fabric to

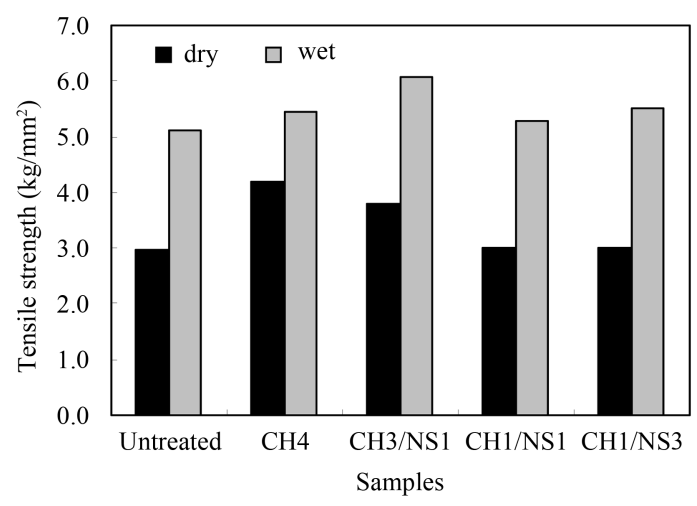

Fig. 5. Tensile strength of the fabrics treated with chitosan/nanosilver colloidal solution. be ellulose facrosslinkagefinishisults in a decrease in strength. However, it appears that the hydrogenntend is housellulosesubstantially by the chitosan/nanosilver colloidal solution treatment. Rather, the tensile strength is thought to have increased due to the adhesion of chitosan.

According to $\langle$ Fig. 6>, stiffness was measured to examine the changes in external properties after the fabric was treated with chitosan/nanosilver colloidal solution. The chitosan treated fabric became stiffer in comparison to the untreated fabric, which is thought to be caused by a reduction in the degree of freedom of the thread due to the formation of film on the surface of the fabric by chitosan. However, the chitosan/ nanosilver treated fabric became softer because the quantity of chitosan was reduced comparatively. It is thought that nanosilver particles adhered evenly on the uneven areas of the fiber making bending more pliable. This tendency was similarly observed in previous research (Jeong et al., 2009). The cotton fabric became softer with a higher ratio of nanosilver.

Cotton fabric wrinkles easily and the shape retention is poor. As such, a wrinkle recovery effect can be expected by treating the fabric with a chitosan/nanosilver colloidal solution. According to $\langle$ Fig. 7$\rangle$, the dry and wet wrinkle recovery angle of the chitosan/nanosilver treated fabric increased in all the specimens regardless of the mixing ratio of the chitosan/nanosilver colloidal solution.

A dry wrinkle recovery angle was slightly reduced

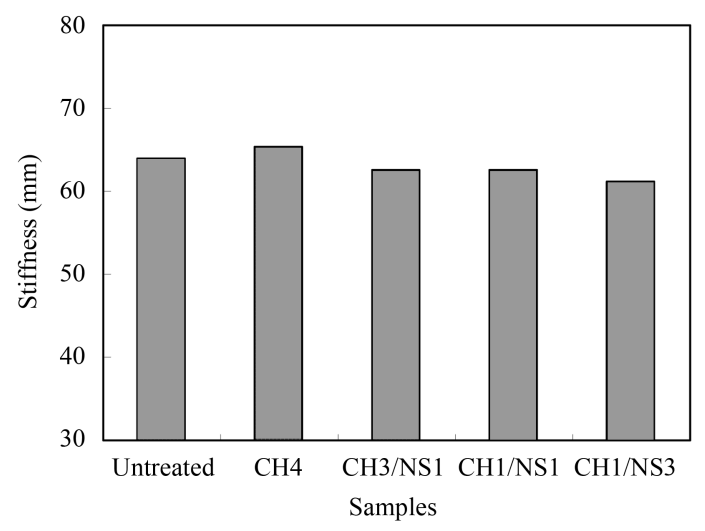

Fig. 6. Stiffness of the fabrics treated with chitosan/ nanosilver colloidal solution. 


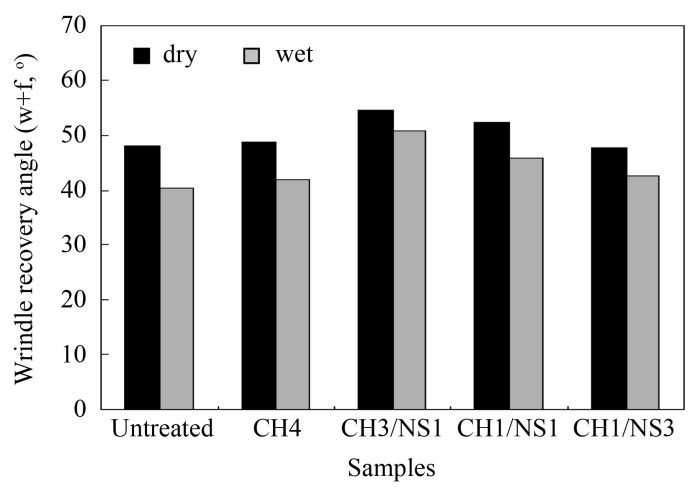

Fig. 7. Wrinkle recovery angle of the fabrics treated with chitosan/nanosilver colloidal solution.

in comparison to the wet wrinkle recovery angle that indicated that wet cotton fabric wrinkles more easily. Furthermore, the treatment of the fabric with chitosan/nanosilver colloidal solution results in a greater wrinkle recovery effect than treatment using only chitosan.

The goal of this research is to obtain functional improvement such as durability and dimensional stability in a cotton fabric used for patient clothing by treating the fabric with a chitosan/nanosilver colloidal solution. The main factors confronted in using cotton fabric such as dimensional stability, pilling resistance, and abrasion resistance were compared. According to $\langle$ Table 5>, all the shrinkage ratios were lowered when treated with a mixed solution with a greater reduction in the shrinkage ratio with a higher nanosilver ratio. This is thought to be caused by reduction of the space to be contracted due to the reduction in the pores the chitosan/nanosilver colloidal solution adheres to on the fabric surface. In particular, such a reduction of the shrinkage ratio in the chitosan/nanosilver treated fabric signifies that the performance has im- proved from the perspective of usage and maintenance of the patient clothing material.

The pilling resistance of the chitosan/nanosilver treated fabric displayed minor reduction in comparison to the untreated fabric. However, fabric treated only with chitosan displayed a slight reduction in the pilling of the fabric, which was recovered again when treated with a nanosilver colloidal solution. This is thought to be caused by a stronger adhesion of the chitosan due to the adhesion of minute nanosilver particles.

It is important to examine the abrasion resistance (durability aspect) since patient clothing material undergoes substantial abrasion. Abrasion resistance of all the treated fabrics was not reduced by the treatment with the finishing agent regardless of the mixing ratio of the chitosan/nanosilver colloidal solution. The abrasion resistance was not reduced, although the finishing process with chitosan/nanosilver colloidal solution undergoes swelling in water and high temperature thermal processing. Accordingly, the chitosan/nanosilver treated cotton fabric used for patient clothing material showed excellent physical properties.

\section{Conclusions}

This research investigated the structural and physical properties of cotton fabric used for the patient clothing material through the chitosan/nanosilver colloidal solution. The fabric was treated with a mixing of chitosan (a natural polymer with excellent biocompatibility) and a nanosilver colloidal solution, for which an additional performance can be expected while supplementing the weaknesses of chitosan, in accordance with the prescribed ratio. The results were compared to the fabric treated only with chitosan.

Table 5. Changes in performance of the fabrics treated with a chitosan/nanosilver colloidal solution

\begin{tabular}{|c|c|c|c|c|}
\hline \multirow{2}{*}{ Samples } & \multicolumn{2}{|c|}{ Shrinkage (\%) } & \multirow{2}{*}{$\begin{array}{l}\text { Pilling } \\
\text { (ranking) }\end{array}$} & \multirow{2}{*}{$\begin{array}{c}\text { Abrasion resistance } \\
\text { (cycles) }\end{array}$} \\
\hline & Warp & Weft & & \\
\hline Untreated & -2 & -2.4 & 4.5 & $>20,000$ \\
\hline $\mathrm{CH} 4$ & -1.5 & -0.5 & 4 & $>20,000$ \\
\hline $\mathrm{CH} 3 / \mathrm{NS} 1$ & -1.5 & -0.5 & 4.5 & $>20,000$ \\
\hline $\mathrm{CH} 1 / \mathrm{NS} 1$ & -1 & -0.5 & 4.5 & $>20,000$ \\
\hline CH1/NS3 & -1 & -0.5 & 4.5 & $>20,000$ \\
\hline
\end{tabular}


1. With regards to the surface characteristics of the chitosan/nanosilver treated fabric, the add-on ratio increased with an increase in the mixing ratio of nanosilver. For $\mathrm{CH} 3 / \mathrm{NS} 1$ treated fabric, the $K / S$ value and color difference was the highest. The crystalline structure of the treated fabric showed minor changes and maintained the structure of cellulose I. The whiteness of the chitosan/nanosilver treated fabric was not reduced.

2 . The dry strength of the chitosan/nanosilver treated fabric increased with a higher ratio of chitosan, while the wet strength increased the most when the nanosilver mixing ratio was $3: 1$. Although, the chitosan treated fabric became stiffer in comparison to the untreated fabric, the fabric became softer with an increase in the nanosilver mixing ratio. Both the dry and wet wrinkle recovery angle improved. For $\mathrm{CH} 3$ / NS1 treated fabrics, the wrinkle recovery effect was the most excellent.

3. Dimensional stability improved with a greater reduction in the shrinkage ratio of the treated fabric with a higher mixing ratio of nanosilver. Pilling and abrasion resistance of the chitosan/nanosilver treated fabric was not reduced by treatment with a finishing agent regardless of the mixing ratio of the chitosan/nanosilver colloidal solution. The chitosan/nanosilver treated cotton fabric used for the patient clothing material showed excellent physical properties.

\section{References}

Hong, J. M. (1999). A study on developing patient clothing of free-size. The Korean Society of Costume, 47, 113124.

Hong, S. H., Kim, R., \& Choi, C. N. (1998). Developing trends of technology in anti-bacterial and odor-preventing finish. Fiber Tech. and Ind., 2(2), 286-295.
Jeong, K. M., Kang, I. S., \& Bae, H. S. (2009). Functional improvement of the clothing material for patients by chitosan/nanosilver mixed solution: The assessment of mechanical properties and hand value. J. of the Korean Soc. of Dyers and Finishers, 21(1), 21-29.

Kim, J. J., Jeon, D. W., \& Hong, J. S. (1995). Technical reviews and news: A suggestion on the chitosan application in the textile finishing and related sectors. Textile Science and Engineering, 32(8), 705-712.

Kim, J. J., Jeon, D. W., \& Kwon, Y. K. (1997). A study on the change of hand of chitosan-treated fabrics (III): Effect of chitosan treatment conditions. Textile Science and Engineering, 34(10), 689-700.

Lee, H. J., \& Jeong, S. H. (2002). Antibacterial finishing and laundering durability on woven fabrics using nanosized silver colloids. Proceeding of SOTSEA, 141-145.

Lee, J. S., Hong, S. I., \& Jeon, D. W. (1994). Synthesis of crosslinked chitosan phosphate and its metal ion adsorption characteristics (I): Crosslinking and phosphorylation of chitosan. Textile Science and Engineering, 31(12), 966-975.

Ogura, K., Itoh, M., Kanamoto, T., \& Tanaka, K. (1980). Dynamic mechanical behavior of chitin and chitosan. Polym. Bull., 2, 301-304.

Oh, K. W., Kim, C. S., \& Choi, H. M. (1997). Application of silane-chitosan mixed solution to cotton finishing (I). Textile Science and Engineering, 34(12), 822-829.

Park, H. W., Ryou, E. J., \& Bae, H. S. (2006). A research and analysis on the design of dementia patient's clothes in domestic. The Korean Society of Costume, 56(6), 4557.

Park, S. H. (2006). A study on clothing for patients. J. Kor. Home Economics Association, 42(6), 13-21.

Samuels, R. J. (1981). Solid state characterization of the structure of chitosan films. J. Polym. Sci., Poly. Phys. Ed., 19, 1081-1105.

Simpson, K. (2003). Using silver to fight microbial attack. Plastics Additives \& Compounding, 5(5), 32-35.

$\mathrm{Xu}$, J., McCarthy, S. P., Gross, R. A., \& Kaplan, D. L. (1996). Chitosan film acylation and effects on biodegradability. Macromolecules, 29(10), 3436-3440.

\section{요 약}

실제 환자복 소재로 사용되는 면직물의 내구성, 치수안정성, 구김회복성 등의 성능을 개선하고 경제적 인 측면을 고려한 기능성 가공을 하기 위하여 가공제로 천연고분자이며 생체적합성이 우수한 키토산과 고착효율이 좋지 않은 키토산의 단점을 보완하면서 부가적인 성능을 기대할 수 있는 은나노 콜로이드용 액을 혼합비에 따라 처리하고, 키토산 단독 처리직물과 비교함으로서 가공처리직물의 구조 및 물리적 특 
성의 변화를 살펴보았다. 은나노 콜로이드용액의 혼합비가 클수록 부착률이 증가하였으며, 키토산/은나 노 콜로이드용액 가공에 따른 결정화도의 저하나 백도 저하도 일어나지 않았다. 건(乾)강도와 강연도는 키토산 단독 처리직물이 가장 좋았으나, 습(濕)강도와 건(乾), 습(濕)방추도는 은나노 콜로이드용액의 혼 합비가 3:1일때 가장 우수하였다. 은나노의 혼합비가 커질수록 가공처리 직물의 치수변화율이 감소하여 형태안정성이 향상되었고, 필링성 및 마모강도도 저하되지 않아 면직물이 환자복 소재로서 내구성이 우 수한 물리적 특성을 나타내었다. 